\title{
Ibuprofen, a drug used in pain, inflammation and fever
}

\author{
Simona Negres \\ Pharmacology and Clinical Pharmacy Department, Faculty of Pharmacy, \\ "Carol Davila" University of Medicine and Pharmacy, Bucharest, Romania
}

\begin{abstract}
Ibuprofen is a non-steroidal antiinflammatory drug (NSAID) derived from propionic acid, used on a large scale both in adults and children for the treatment of pain, fever and inflammation of different etiologies. Many randomized clinical trials controlled against placebo or active substances support the efficacy of ibuprofen, administered alone or in combinations, single or repeated dose, in these pathological states. Literature safety data show that ibuprofen is one of the most utilized NSAIDs owing to its efficacy and reduced adverse events profile.
\end{abstract}

Keywords: ibuprofen, pain, inflammation, fever, children, paracetamol, otalgia, sore throat

\section{INTRODUCTION}

Ibuprofen is the widest administered medicine from the non-steroidal anti-inflammatory class, for the treatment of inflammation, fever and mild to moderate pain; having a high safety profile. The main mechanism to reduce fever, inflammation and pain in children is the pro-inflammatory prostaglandins synthesis reduction, at peripheral and central level.

\section{The efficacy of ibuprofen as analgesic and anti- pyretic in children}

The efficacy of ibuprofen has been evaluated comparatively with other antipyretic medicines: paracetamol, noraminofenazone, ketoprofen, in children with fever (caused by viral or bacterial infections). In these studies, the pediatric patients received a wide range of ibuprofen doses: 4-5-10-15 $\mathrm{mg} / \mathrm{kg}$ of body weigh/dose, depending on age. The results of the clinical studies showed that ibuprofen is effective in the reduction of fever, pain and inflammation, with a faster onset of the effect and maintaining it for 6 hours. Other studies comparatively evaluated the regimens of ibuprofen alternating with paracetamol and mono-therapy. The re- sults of these studies are controversial, some are claiming the superior efficacy of the alternating therapy, while others are contradicting these outcomes.

Some other studies on children underlined the reduction of the incidence of post-vaccinal adverse effects; by prophylactic administration of 10-15 $\mathrm{mg} / \mathrm{kg} /$ dose of ibuprofen $(12,20)$. In table 1 they are shown some of the recently published comparative efficacy studies, with ibuprofen for children.

The most recent citation from the literature is a meta-analysis published by Poddighe et al. (2018) (28) in Pediatric Emergency with a suggestive title: "Ibuprofen in pain control for children - a new value for an old molecule". The authors aim was to discuss the existent proofs on ibuprofen clinical usage, published in PubMed and Medline databases between 1985 and 2017 and to compare them with paracetamol and/or codeine, according available data. The pediatric indications considered were sore throat, otalgia, dental pain, headache, posttraumatic musculoskeletal pain and pot-operative pain.

For sore throat they were selected two randomized, double-blind studies, placebo-controlled $(3,32)$, which compared the efficacy of ibuprofen, 
TABLE 1. Clinical studies on ibuprofen efficacy to treat pain, fever and inflammation in children

\begin{tabular}{|c|c|c|}
\hline Reference & The study objective & Conclusions \\
\hline $\begin{array}{l}\text { Perrot et al., } \\
2004(26)\end{array}$ & $\begin{array}{l}\text { To investigate the efficacy and safety of ibuprofen } \\
\text { for feverish children }(n=186) \text { comparatively with } \\
\text { paracetamol. }\end{array}$ & $\begin{array}{l}\text { In children, the unique doses of ibuprofen }(4-10 \mathrm{mg} / \mathrm{kg}) \text { and } \\
\text { paracetamol ( } 7-15 \mathrm{mg} / \mathrm{kg}) \text { had a similar efficacy and safety for } \\
\text { alleviating mild to moderate pain. When used as antipyretic, } \\
\text { ibuprofen }(5-10 \mathrm{mg} / \mathrm{kg}) \text { was more effective vs. paracetamol } \\
(10-15 \mathrm{mg} / \mathrm{kg}) \text { at } 2,4 \text { and } 6 \text { hours after administration. }\end{array}$ \\
\hline $\begin{array}{l}\text { Goldman et al., } \\
2004 \text { (9) }\end{array}$ & $\begin{array}{l}\text { To compare the antipyretic effect and safety profiles } \\
\text { of ibuprofen and paracetamol in feverish children. }\end{array}$ & $\begin{array}{l}\text { There were analyzed data published in databases: Medline } \\
(1966-2003) \text { and Embase (1988-2003). Ibuprofen was } \\
\text { significantly more effective vs. paracetamol in reducing fever } \\
\text { after a single dose, maintaining the effect for } 6 \text { hours after the } \\
\text { treatment. }\end{array}$ \\
\hline $\begin{array}{l}\text { Hay et al., } \\
2009(11)\end{array}$ & $\begin{array}{l}\text { To compare the antipyretic efficacy of paracetamol } \\
(15 \mathrm{mg} / \mathrm{kg} ; 4 \text { doses } / 24 \text { hours) and ibuprofen }(10 \\
\mathrm{mg} / \mathrm{kg} ; 3 \text { doses } / 24 \text { hours }) \text { in feverish children } \\
\left(\geq 37.8^{\circ} \mathrm{C} ;<40^{\circ} \mathrm{C}\right) .\end{array}$ & $\begin{array}{l}\text { Ibuprofen was faster and more effective in reduction of fever } \\
\text { in children, comparatively with paracetamol. }\end{array}$ \\
\hline $\begin{array}{l}\text { Paul et al., } \\
2010(25)\end{array}$ & $\begin{array}{l}\text { Comparative antipyretic efficacy study in children, } \\
\text { with } 3 \text { regimens: ibuprofen in monotherapy, } \\
\text { ibuprofen combined with paracetamol, ibuprofen } \\
\text { followed by paracetamol (the observation period: } \\
6 \text { hours). }\end{array}$ & $\begin{array}{l}\text { Higher efficacy in case of the ibuprofen and paracetamol } \\
\text { association regimens. }\end{array}$ \\
\hline $\begin{array}{l}\text { Sarell et al., } \\
2006(30)\end{array}$ & $\begin{array}{l}\text { To compare the antipyretic efficacy in children aged } \\
6-36 \text { months of ibuprofen ( } 5 \mathrm{mg} / \mathrm{kg} \text { every } 8 \text { hours) } \\
\text { and paracetamol ( } 12.5 \mathrm{mg} / \mathrm{kg} \text { every } 6 \text { hours) as } \\
\text { monotherapy and alternating therapy (use of both } \\
\text { medicines). }\end{array}$ & $\begin{array}{l}\text { The alternating therapy with paracetamol } 12,5 \mathrm{mg} / \mathrm{kg} \text { and } \\
\text { ibuprofen } 5 \mathrm{mg} / \mathrm{kg} \text { administrated every } 4 \text { hours proved to be } \\
\text { more effective in reducing fever vs. monotherapy. }\end{array}$ \\
\hline $\begin{array}{l}\text { Magni et al., } \\
2011(18)\end{array}$ & $\begin{array}{l}\text { To compare efficacy and safety of ibuprofen and } \\
\text { noraminofenazone in feverish children }(80) \text { aged } 6 \\
\text { months- } 8 \text { years. }\end{array}$ & $\begin{array}{l}\text { An unique dose of ibuprofen has a superior antipyretic efficacy } \\
\text { vs. noraminofenazone. }\end{array}$ \\
\hline $\begin{array}{l}\text { Wong et al., } \\
2014 \text { (36) }\end{array}$ & $\begin{array}{l}\text { To compare the efficacy of ibuprofen or } \\
\text { paracetamol monotherapies with the alternative } \\
\text { therapy regimen, using the } 2 \text { actives. }\end{array}$ & $\begin{array}{l}\text { Ibuprofen and paracetamol administered as monotherapy had } \\
\text { comparable efficacy in fever reduction vs. alternative therapy } \\
\text { regimen. }\end{array}$ \\
\hline
\end{tabular}

placebo and paracetamol and which concluded that both medicines were equally effective. Similar outcomes came out from a more recent meta-analyses (27) on safety and efficacy of ibuprofen and paracetamol in both children and adults.

Both medicines are recommended in sore throat guidelines, without a consensus on the combined therapy. In selected cases, with major exudative compound and/or local adenopathy, including the Group A streptococcal pharyngitis, ibuprofen is preferred, due to its anti-inflammatory properties (5).

For otalgia it was considered the study published by Bertin et al. (1991) (3) which included 219 children (aged 1-6 years) with otitis media, treated with ibuprofen for 48 hours. The efficacy of the two actives was comparable.

A systematic review of the recent literature (33) regarding the efficacy of paracetamol and the nonsteroidal anti-inflammatories, including ibuprofen, in the treatment of otitis media concluded that there is a therapeutic equivalence of both actives at 24 and 48 hours, without differences in adverse reactions. Even more, there wasn't documented supe- riority of the combination of ibuprofen and paracetamol vs. monotherapy.

For dental pain (caused by cavities or after stomatological procedures) ibuprofen proved to be more effective vs. paracetamol (1). There is a remarkable pediatric study on children aged 5-12 years, with dental pain, where ibuprofen controlled the pain as effective as the combination of paracetamol-codeine (23). Another pediatric study on children aged 12-16 years, that suffered stomatology procedures, compared ibuprofen and paracetamol in dental pain and showed that a dose of $400 \mathrm{mg}$ ibuprofen administered before the procedure and an identical one 6 hours after ensured a greater pain reduction than the similar scheme using $1000 \mathrm{mg}$ paracetamol (6).

For the acute headache in children, paracetamol and ibuprofen are the most used $(13,31)$. More clinical studies demonstrated the efficacy of ibuprofen in reducing headache (effect measured 2 hours post-administration) $(3,8)$. Only few studies compared ibuprofen $(10 \mathrm{mg} / \mathrm{kg})$ with other medicines. Among these, the study conducted by Hämäläinen et al. (1997)(10) compared the effica- 
cy of ibuprofen vs. placebo and vs. paracetamol (15 $\mathrm{mg} / \mathrm{kg}$ ), concluding that the efficacy of ibuprofen was greater vs. paracetamol.

For the post-traumatic musculoskeletal pain, ibuprofen also proved to be very useful (15). The most recent systemic review (16) of the literature selected 8 controlled, randomized clinical studies, which enrolled 1,169 children (aged 3-8 years), and showed that ibuprofen it's a stronger analgesic vs. paracetamol or codeine, being equivalent to the association of the last two actives and with fewer adverse effects. One study published by Clark et al. (2007) (6) on the treatment of the acute traumatic musculoskeletal pain in children and adolescents (aged 6-17 years) where unique doses of paraceta$\mathrm{mol}(15 \mathrm{mg} / \mathrm{kg})$, ibuprofen $(10 \mathrm{mg} / \mathrm{kg})$ and codein $(1 \mathrm{mg} / \mathrm{kg})$ where administred, showed a greater improve of the pain score after the administration of ibuprofen vs. the two comparators. Onother clinical study (7), on 336 children with musculo-scheletal enjuries and lims fractures, underlined an equivalent reduction of pain after ibuprofen or the association of paracetamol-codein, but with more adverse effects in case of the paracetamol-codein association. În 2014, Poonai et al. (29) compared the analgetic action of morfin and ibuprofen on 134 children with un-complicated limb fractures, concluding that the analgetic efficacy was comparable.

For the post-surgical pain we consider the observation that $40-60 \%$ cases of algic syndromes after surgery in children are under-treated because of the difficulty of evaluation of the pain intensity in new-borned and babies, because of the concern on potential adverse effects and because of the low number of analgetics that are approved for pediatric use (4).

\section{The safety profile of ibuprofen administred to children}

For ibuprofen, one of the most studied NSAI to the pediatric population, have been identified the highest safety and efficacy profiles $(14,27)$. Considering the recent limitations on opioids prescription imposed by EMEA (2015) and FDA (2017), analgesics are to be reconsidered and among them, ibuprofen it's clearly advantageous. In 2003, Kokki (30) evaluated the efficacy of ibuprofen in preventing pain after minor surgery for hernias, phimosis, hydrocele and hypospadias by randomizing 81 children (aged 1-4 years) who received intrarectal ibuprofen or placebo during anesthesia. Ibuprofen significantly reduced pain during first hours after procedures and reduced the morphine consumption (similar results have been obtained by Stewart et al., 2012) (35). In older studies (34) who compared the efficacy of ibuprofen with the paracetamol/codeine association, the advantage of low bleeding risk went to the association; while in the recent retrospective researches $(2,8,17,21)$, the confirmed analgesic efficacy went to ibuprofen for children in the post-surgical pain, with no increase in bleeding risk.

Other three prospective studies in pediatric patients have been evaluated the safety and efficacy of ibuprofen in post-tonsillectomy pain:

- Children aged 6-14 years treated with ibuprofen $(24 \mathrm{mg} / \mathrm{kg} /$ day $)$, paracetamol (48 $\mathrm{mg} / \mathrm{kg} /$ day) or the alternating association between the two medicines, for 48 hours after surgery (22). The study demonstrated the analgesic equivalence of the three therapeutic regimens.

- Children after tonsillectomy aged 6-17 years treated with ibuprofen iv $(10 \mathrm{mg} / \mathrm{kg})$ or placebo (24). The clinical study observed a significant reduction of fentanyl utilization, without risk of complications, including post-surgery bleeding.

- Children aged 1-10 years who needed tonsillectomy and/or adenoidectomy received ibuprofen or the association of paracetamol/ morphine (29). The results of the study showed similar analgesic efficacy with the advantage of no morphine induced respiratory depresa, in case of ibuprofen use.

Other recent researches positioned the ibuprofen use as a valid option for opioids usage reduction in treating pain after surgery $(19,34)$.

In a prospective study, double blind, randomized, placebo controlled, to compare the efficacy of prophylactic administration of ibuprofen, paracetamol or placebo to reduce the pain in children, after dental extraction (45 children aged 6-12 years), the results highlighted a superior efficacy of ibuprofen, with lower pain scores $(p<0.05)$ comparative with paracetamol.

\section{CONCLUSIONS}

Ibuprofen is a non-selective inhibitor of COX1 and $\mathrm{COX} 2$ and is widely used for children, in treating fever and pain of different etiologies. The medical literature contains vast data to support the safety and efficacy of ibuprofen administered as OTC medicine. 


\section{REFERENCES}

1. Ashley PF, Parekh S, Moles DR, Anand P, MacDonald LC. Preoperative analgesics for additional pain relief in children and adolescents having dental treatment. Cochrane Database Syst Rev. 2016 Aug 8;(8):CD008392.

2. Bedwell JR, Pierce M, Levy M, Shah RK. Ibuprofen with acetaminophen for postoperative pain control following tonsillectomy does not increase emergency department utilization. Otolaryngol Head Neck Surg. 2014 Dec;151(6):963-6.

3. Bertin L, Pons G, d'Athis P, Lasfargues G, Maudelonde C, Duhamel $\mathrm{JF}$, Olive G. Randomized, double-blind, multicenter, controlled trial of ibuprofen versus acetaminophen (paracetamol) and placebo for treatment of symptoms of tonsillitis and pharyngitis in children. J Pediatr. 1991 Nov;119(5):811-4.

4. Brasher C, Gafsous B, Dugue S, Thiollier A, Kinderf J, Nivoche Y, Grace R, Dahmani S. Postoperative pain management in children and infants: An update. Paediatr Drugs. 2014 Apr;16(2):129-40.

5. Chiappini E, Principi N, Mansi N, Serra A, De Masi S, Camaioni A, Esposito S, Felisati G, Galli L, Landi M, Speciale AM, Bonsignori F, Marchisio P, de Martino M; Italian Panel on the Management of Pharyngitis in Children. Management of acute pharyngitis in children: summary of the Italian National Institute of Health guidelines. Clin Ther. 2012 Jun;34(6):1442-1458.e2.

6. Clark E, Plint AC, Correll R, Gaboury I, Passi B. A randomized, controlled trial of acetaminophen, ibuprofen, and codeine for acute pain relief in children with musculoskeletal trauma. Pediatrics. 2007 Mar;119(3):460-7.

7. Drendel AL1, Gorelick MH, Weisman SJ, Lyon R, Brousseau DC, Kim MK. A randomized clinical trial of ibuprofen versus acetaminophen with codeine for acute pediatric arm fracture pain. Ann Emerg Med. 2009 Oct:54(4):553-60.

8. D'Souza JN, Schmidt RJ, Xie L, Adelman JP, Nardone HC. Postoperative nonsteroidal anti-inflammatory drugs and risk of bleeding in pediatric intracapsular tonsillectomy. Int J Pediatr Otorhinolaryngol. 2015 Sep;79(9):1472-6.

9. Goldman RD, Ko K, Linett LJ, Scolnik D. Antipyretic efficacy and safety of ibuprofen and acetaminophen in children. Ann Pharmacother. 2004 Jan;38(1):146-50.

10. Hämäläinen ML, Hoppu K, Valkeila E, Santavuori P. Ibuprofen or acetaminophen for the acute treatment of migraine in children: a double-blind, randomized, placebo-controlled, crossover study. Neurology. 1997 Jan;48(1):103-7.

11. Hay AD, Redmond NM, Costelloe C, Montgomery AA, Fletcher M, Hollinghurst S, Peters TJ. Paracetamol and ibuprofen for the treatment of fever in children: the PITCH randomised controlled trial. Health Technol Assess. 2009 May;13(27):iii-iv, ix-x, 1-163.

12. Jackson LA, Dunstan M, Starkovich P, Dunn J, Yu O, Nelson JC, Rees T, Zavitkovsky A. Prophylaxis with acetaminophen or ibuprofen for prevention of local reactions to the fifth diphtheria-tetanus toxoids-acellular pertussis vaccination: a randomized, controlled trial. Pediatrics. 2006 Mar;117(3):620-5.

13. Jeric M, Surjan N, Jelicic Kadic A, Riva N4, Puljak L. Treatment of acute migraine attacks in children with analgesics on the World Health Organization Essential Medicines List: A systematic review and GRADE evidence synthesis. Cephalalgia. 2018 Aug;38(9):1592-1607.

14. Kanabar DJ. A clinical and safety review of paracetamol and ibuprofen in children. Inflammopharmacology. 2017;25:1-9.

15. Korownyk C, Young J, Michael Allan G. Optimal pain relief for pediatric MSK injury. Can Fam Physician. 2015 Jun;61(6):e276.

16. Le May S, Ali S, Khadra C, Drendel AL, Trottier ED, Gouin S, Poonai N. Pain Management of Pediatric Musculoskeletal Injury in the Emergency Department: A Systematic Review. Pain Res Manag. 2016;2016:4809394.

17. Liu C and Ulualp SO. Outcomes of an alternating ibuprofen and acetaminophen regimen for pain relief after tonsillectomy in children. Ann Otol Rhinol Laryngol. 2015;124:777-781.

18. Magni AM, Scheffer DK, Bruniera P. Antipyretic effect of ibuprofen and dipyrone in febrile children. J Pediatr (Rio J). 2011 JanFeb;87(1):36-42.
19. Mahgoobifard M, Mirmesdagh Y, Imani F, Najafi A, Nataj-Majd M. The analgesic efficacy of preoperative oral ibuprofen and acetaminophen in children undergoing adenotonsillectomy: A randomized clinical trial. Anesth Pain Med. 2014 Feb 28;4(1):e15049. doi: 10.5812/ aapm.15049.

20. Manley J, Taddio A. Acetaminophen and ibuprofen for prevention of adverse reactions associated with childhood immunization. Ann Pharmacother. 2007 Jul;41(7):1227-32.

21. Mattos JL, Robison JG, Greenberg J, Yellon RF. Acetaminophen plus ibuprofen versus opioids for treatment of post-tonsillectomy pain in children. Int J Pediatr Otorhinolaryngol. 2014 Oct;78(10):1671-6.

22. Merry AF, Edwards KE, Ahmad Z, Barber C, Mahadevan M, Frampton C. Randomized comparison between the combination of acetaminophen and ibuprofen and each constituent alone for analgesia following tonsillectomy in children. Can J Anaesth. 2013 $\operatorname{Dec} ; 60(12): 1180-9$

23. Moore PA, Acs G, Hargreaves JA. Postextraction pain relief in children: A clinical trial of liquid analgesics. Int J Clin Pharmacol Ther Toxicol. 1985 Nov;23(11):573-7.

24. Moss JR, Watcha MF, Bendel LP, McCarthy DL, Witham SL, Glover $\mathrm{CD}$. A multicenter, randomized, double-blind placebo-controlled, single dose trial of the safety and efficacy of intravenous ibuprofen for treatment of pain in pediatric patients undergoing tonsillectomy. Paediatr Anaesth. 2014 May;24(5):483-9.

25. Paul IM, Sturgis SA, Yang C, Engle L, Watts H, Berlin CM Jr. Efficacy of standard doses of Ibuprofen alone, alternating, and combined with acetaminophen for the treatment of febrile children. Clin Ther. 2010 Dec;32(14):2433-40.

26. Perrott DA, Piira T, Goodenough B, Champion GD. Efficacy and safety of acetaminophen vs ibuprofen for treating children's pain or fever: a meta-analysis. Arch Pediatr Adolesc Med. 2004 Jun;158(6):521-6.

27. Pierce CA , Voss B. Efficacy and safety of ibuprofen and acetaminophen in children and adults: a meta-analysis and qualitative review. Ann Pharmacother. 2010;44:489-506.

28. Poddighe D, Brambilla I, Licari A, Marseglia GL. Ibuprofen for Pain Control in Children: New Value for an Old Molecule. Pediatr Emerg Care. 2018 Jun 14. doi: 10.1097/PEC.0000000000001505.

29. Poonai N, Datoo N, Ali S, Cashin M, Drendel AL, Zhu R, Lepore N, Greff M, Rieder M, Bartley D. Oral morphine versus ibuprofen administered at home for postoperative orthopedic pain in children: A randomized controlled trial.CMAJ. 2017 Oct 10;189(40):E1252-E1258.

30. Richer L, Billinghurst L, Linsdell MA, Russell K, Vandermeer B, Crumley ET, Durec T, Klassen TP, Hartling L. Drugs for the acute treatment of migraine in children and adolescents. Cochrane Database Syst Rev. 2016 Apr 19;4:CD005220.

31. Sarrell EM, Wielunsky E, Cohen HA. Antipyretic treatment in young children with fever: acetaminophen, ibuprofen, or both alternating in a randomized, double-blind study. Arch Pediatr Adolesc Med. 2006 Feb;160(2):197-202.

32. Schlachtel BP, Thoden WR. A placebo-controlled model for assaying systemic analgesics in children. Clin Pharmacol Ther. 1993;53:593-601.

33. Sjoukes A, Venekamp RP, van de Pol AC, Hay AD, Little P, Schilder AG, Damoiseaux RA. Paracetamol (acetaminophen) or non-steroidal anti-inflammatory drugs, alone or combined, for pain relief in acute otitis media in children. Cochrane Database Syst Rev. 2016 Dec 15;12:CD011534.

34. St Charles CS, Matt BH, Hamilton MM, Katz BP. A comparison of ibuprofen versus acetaminophen with codeine in the young tonsillectomy patient. Otolaryngol Head Neck Surg. 1997 Jul;117(1):76-82.

35. Stewart DW, Ragg PG, Sheppard S, Chalkiadis GA. The severity and duration of postoperative pain and analgesia requirements in children after tonsillectomy, orchidopexy, or inguinal hernia repair. Paediatr Anaesth. 2012 Feb;22(2):136-43.

36. Wong T, Stang AS, Ganshorn H, Hartling L, Maconochie IK, Thomsen AM, Johnson DW. Combined and alternating paracetamol and ibuprofen therapy for febrile children. Evid Based Child Health. 2014 Sep;9(3):675-729. 